\title{
Correlation of methylation of toll-like receptor 4 (TLR4) and interleukin-6 (IL6) promoter with insulin resistance in obese adolescents
}

\author{
Ratih Feraritra Danu Atmaja ${ }^{1}$, Dian Caturini Sulistyonigrum ${ }^{2}$, Emy Huriyati ${ }^{2}$, Ahmad Hamim \\ Sadewa ${ }^{1}$, Rina Susilowati ${ }^{3 *}$ \\ ${ }^{1}$ Department of Biochemistry, ${ }^{2}$ Department of Nutrition and Health, ${ }^{3}$ Department of \\ Histology and Cell Biology, Faculty of Medicine, Universitas Gadjah Mada, Yogyakarta, \\ Indonesia
}

DOI: http://dx.doi.org/10.19106/JMedSci004801201602

\begin{abstract}
Chronic inflammation can lead to insulin resistance in obesity. Increased mRNA expression of inflammatory markers such as toll-like receptor 4 (TLR4) and interleukin 6 (IL6) were reported both in the tissue and the peripheral blood of obese adolescent and correlated with insulin resistance. DNA methylation surrounding TSS region is known to regulate the level of a gene expression. The aim of the study was to investigate the methylation status of TLR4 and IL6 promoter in peripheral blood of obese adolescent and its correlation to insulin resistance. This was a cross sectional study with observational analytic approached. Fifty adolescents with obesity from Yogyakarta Special Region, aged 15-18 years, $z$-score value $>2 S D$, no experience of any acute infections within 2 weeks and signed in informed consent, were selected in this study. Subjects with diabetic mellitus, incomplete data and DNA concentration of $<20 \mu \mathrm{g} / \mathrm{mL}$ were excluded. DNA samples were extracted from peripheral blood of the subjects. The bisulfite converted DNA was analyzed for methylation level with direct sequencing. Correlation analysis using Spearman test was performed with significance value was set at $p<0.05$. No methylation in TLR4 promoter was detected in all subjects. The methylation level of IL 6 was transformed to categorical variable. Four $(8 \%)$ subjects with insulin resistance and $2(4 \%)$ without insulin resistance had methylation on a CpG site. Methylation of IL6 was not statisticaly different between insulin resistance and non-resistance adolescent $(p=0.635)$. The significant correlation was not found between methylation level in IL6 promoter with insulin resistance (HOMAIR) $(r=0.051)$. Cell specific of methylation mechanism, characteristic of subjects and types of samples were suspected causing those results. In conclusion, no correlation between methylation levels of TLR4 promoter and IL6 with insulin resistance in obese adolescent was observed in this study.
\end{abstract}

Keywords: obesity - methylation - TLR4 - IL6 - direct sequencing 


\section{ABSTRAK}

Inflamasi kronis dapat menyebabkan resistensi insulin pada obesitas. Peningkatan ekspresi mRNA pada penanda inflamasi seperti toll-like receptor 4 (TLR4) dan interleukin 6 (IL6) dilaporkan terjadi di jaringan dan darah tepi pada remaja obes dan berhubungan dengan resistensi insulin. Metilasi DNA di sekitar regio Transcriptional Start Site (TSS) berperan pada pengaturan ekspresi gen. Penelitian ini bertujuan untuk mengkaji status promoter TLR4 dan IL6 darah tepi remaja obes dan hubungannya dengan resistensi insulin. Rancangan studi potong lintang dengan pendekatan analitik observasional digunakan pada penelitian ini. Penelitian melibatkan 50 remaja obes di Daerah Istimewa Yogyakarta (DIY), berumur 15-18 tahun, mengalami obesitas dengan skor $z>2$ SD, tidak memiliki riwayat infeksi akut selama 2 minggu terakhir dan menandatangani surat pernyataan persetujuan keikut sertaan dalam penelitian. Kriteria eksklusi adalah subjek dengan diabetes mellitus, data tidak lengkap, dan konsentrasi DNA $<20 \mu \mathrm{g} / \mathrm{mL}$. Sampel DNA diekstraksi dari darah tepi untuk selanjutnya dikonversi dengan bisulfit, dan dianalisis untuk mengetahui tingkat metilasi dengan sekuensing DNA secara langsung. Analisis statistik dilakukan menggunakan uji korelasi Spearman dengan nilai kemaknaan $p<0,05$. Hasil penelitian menunjukkan bahwa metilasi pada promoter TLR4 tidak terdeteksi pada seluruh subjek. Tingkat metilasi IL6 diubah menjadi variabel kategorik. Empat $(8 \%)$ subjek dengan resitensi insulin dan 2 (4\%) subjek sensitif insulin menunjukkan metilasi pada sisi $\mathrm{CpG}$. Metilasi pada IL6 secara statistik tidak menunjukkan adanya perbedaan bermakna antara remaja dengan resistensi insulin dan sensitif resistensi $(p=0.635)$. Tidak ada hubungan antara tingkat metilasi promoter IL6 dengan resistensi insulin (HOMA-IR) $(r=0.051)$. Mekanisme metilasi spesifik sel, karakteristik subjek dan tipe-tipe sampel diduga berpengaruh terhadap hasil yang diperoleh pada penelitian ini. Kesimpulan dari penelitian ini adalah tidak adanya hubungan antara tingkat metilasi promoter TLR4 dan IL6 dengan resistensi insulin pada remaja obes.

\section{INTRODUCTION}

Indonesia has been included in top 10 countries with the highest prevalence of obesity in the world. ${ }^{1}$ The prevalence of obese adolescent in Indonesia increased from $1.4 \%$ in 2007 to $7.3 \%$ in $2013 .^{2}$ Around $5.7 \%$ adolescents aged 16-18 years is overweight, while $1.6 \%$ is included in the category of obese. ${ }^{2}$ Yogyakarta Special Region is a province in Indonesia that has the highest prevalence of adolescent obesity in 2010 and as one of the cities where the prevalence of obese adolescent prevalence above the national average in 2013. ${ }^{2,3}$

Obesity at a young age will give longterm health impacts, for example the tendency of being obese in adulthood, increasing the risk of developing degenerative diseases such as type 2 diabetes mellitus (T2DM), hypertension, ischemia and stroke, until a decline in life expectancy (life expectance). ${ }^{4-6}$ Insulin resistance (IR) is one of major factors which cause T2DM manifestation. The level of IR by homeostatic model assessmentinsulin resistance (HOMA-IR) is known having linear correlation with body mass index (BMI) and fat deposition percentage in adolescent. $^{\text {? }}$

Inflammation is the most studied pathway to explain individuals with obesity may develop to insulin resistance. This pathway includes inflammatory activation through toll-like receptor 4 (TLR4) and interleukin 6 (IL6). The pro-inflammatory enzymes activated either by of TLR4 or IL6 may interfere insulin signaling transduction by targeting insulin receptor substrate (IRS). ${ }^{8-10}$ 
The increase of expressing gene of TLR4 and IL6 has been reported in obese and T2DM. ${ }^{11,12}$ This increase mainly occur in insulin targeting cells such as adipocytes, hepatocytes, and skeletal muscle cells. ${ }^{13-15}$ One of mechanisms which regulate the level of gene expression is DNA methylation. Although the status and level of methylation is specific to each type of cell but the increase of mRNA TLR4 and IL6 has been reported in polymorphnuclear cell of individuals with obesity and positively correlates with insulin resistance. ${ }^{11,16}$ It has been suggested that there is DNA methylation regulation which cause such increase. However, there was no report about the status of promoter methylation of IL6 and TLR4 with IR in obese adolescent's peripheral blood. This study aims to investigate how the level of the status of promoter methylation of IL6 and TLR4 in obese adolescent and its correlation with insulin resistance.

\section{MATERIALS AND METHODS}

\section{Subjects}

Samples of this study was a part of samples from the study conducted by Huriaty in 2014 (unpublished). In the previous study, 4000 adolescents from 10 senior high schools in Yogyakarta Special Region followed screening tests such as height $(\mathrm{cm})$ and weight $(\mathrm{kg})$ for grouping by nutritional status. Following the exclusion of subjects with the history of T2DM and kidney diseases, as many as 263 adolescents, aged $15-18$ years, was not having any infection in 2 weeks (confirmed by questionnaire and medical examination by doctor), and both of parents and adolescents signed the informed consent, enrolled in the present study as subjects. Blood samples were collected following 10-12 fasting overnight in tube containing EDTA. The collected blood were centrifuged to separate its composition. Blood plasma were used for measurement of biochemical parameters. The remaining precipitate including buffycoat were stored in $4^{\circ} \mathrm{C}$ until used. In this study, 50 obese subjects followed by the data such as fasting glucose blood $(\mathrm{mg} / \mathrm{dL})$, insulin level $(\mathrm{mg} / \mathrm{dL})$ and HOMA-IR were chosen by random sampling with sex stratification from the previous study. This study was approved by the Medical and Health Research Ethics Committee of the Faculty of Medicine, Universitas Gadjah Mada, Yogyakarta.

Obese adolescent were defined according to Indonesia Basic Health Research (2013) and WHO (2007) as those having z-score of $>$ 2. Insulin resistance were defined as HOMAIR $>3.2 .{ }^{17}$ Fasting blood glucose $\geq 126 \mathrm{mg} /$ dl was defined as T2DM. ${ }^{2}$ Value of HOMAIR $>3.2$ was defined as insulin resistance. Methylation level of each subject was defined as an average of methylation level of all $\mathrm{CpG}$ in target region based on chromatogram from sequencing results. Methylation level of each $\mathrm{CpG}$ was calculated by Lewin's equations. ${ }^{18}$

\section{DNA extraction and bisulfite treatment}

Genomic DNA was extracted by DNA genomic Promega Wizard $\AA$ Genomic DNA Purification Kit. Four hundred nanogram of genomic DNA was used for bisulfite treatment according to the procedure of EZ - methylation Zymo Gold Kit with a total elution volume of $10 \mathrm{~mL}$ and stored at $-20^{\circ} \mathrm{C}$.

\section{Amplification of target region}

Region target of IL6 at -290 to +10 was amplified using primer forward AGTTATTAATAAAAGAAAAA-3' and reverse 5'- ACAAAATAAACCTCAAACATCTC-3'. While primer for TLR4 amplification were forward 5'-GTTTTTTTAGTTATTGGTTTGTAGG-3' and reverse 5'AAACAAACATCATCCTAACATCATC-3' which is targeting region at -94 to +202 . Cycling condition for amplification of IL6 
were $95^{\circ} \mathrm{C}$ for 5 minutes, 50 cycle of $95^{\circ} \mathrm{C}$ for 1 minute, $55^{\circ} \mathrm{C}$ for 1 minute dan $72^{\circ} \mathrm{C}$ for 1 minute 50 and final extension for 5 minute at $72^{\circ} \mathrm{C}$. Similar cycling condition was used for TLR4 amplification except for annealing temperature was $60^{\circ} \mathrm{C}$ for 1 minute. The PCR product was stored at $4^{\circ} \mathrm{C}$ until being used. Primer used in this study was designed using Meth Primer. ${ }^{19}$

\section{Direct sequencing}

Thirthy microliter of PCR product and 10 $\mu 1$ sent to $1^{\text {st }}$ base to be sequenced by Sanger method. Sequencing of IL6 used forward primer whereas TLR4 used reverse primer. PCR clean-up and sequencing protocol was done according to daily protocol of $1^{\text {st }}$ base.

\section{Statistical analysis}

Data were presented as mean \pm standard deviation (SD) or as median (minimummaximum) depending on the types of data. The mean difference between groups was tested using unpaired t-test. Correlation analysis between methylation of TLR4 and IL6 promoter was performed using Spearman test. The differences between groups were considered statistically significant if a $p$ value $<0.05$.

\section{RESULTS}

The chracteristics of subject are presented in TABLE 1 . Fifty 50 adolescents with obesity consisting of $25(50 \%)$ male and $25(50 \%)$ female from Yogyakarta Special Region were involved in this study. The mean age of subjects was $16.77 \pm 0.72$ years. $Z$-score value mean obtained based on the WHO criteria was $3.8 \pm 0.97$. Median level of fasting blood glucose, insulin and HOMA-IR values, were $84.5(68.0-13.0), 19.28(7.08-52.96)$ and 4.35 (1.7-10.1), respectively. A total of $68 \%$ of the total subjects in this study had insulin resistance. The data were then grouped based on the status of insulin resistance by gender stratification to analyse the mean difference between groups.

TABLE 1. Subject characteristics

\begin{tabular}{ll}
\hline Variables & Value $(\mathrm{n}=50)$ \\
\hline Sex & \\
• Male & $25(50 \%)$ \\
$\quad$ Female & $25(50 \%)$ \\
Age (years) & $16.77 \pm 0.72^{\mathrm{a}}$ \\
Z-Score & $3.8 \pm 0.97^{\mathrm{a}}$ \\
FBG $(\mathrm{mg} / \mathrm{dL})$ & $84.5(68.0-113.0)^{\mathrm{b}}$ \\
Insulin $(\mu \mathrm{IU} / \mathrm{mL})$ & $19.28(7.08-52.96)^{\mathrm{b}}$ \\
HOMA-IR & $4.35(1.7-10.1)^{\mathrm{b}}$ \\
Non-Insulin resistance & $16(32 \%)$ \\
(Non-IR) & $34(68 \%)$ \\
Insulin resistance (IR) & \\
\hline
\end{tabular}

a Presented in mean \pm standard deviation (SD)

${ }^{\mathrm{b}}$ Presented in median value (minimum-maximum)

Mean difference of age and z-score was performed using unpaired t-test whereas FBG level, insulin level, and HOMA-IR was performed using Mann Whitney test. The age of subjects was similar across groups. Z-score values and FBG level was significantly different within female between the insulin resistance and non-insulin resistance groups $(p<0.05)$ but not in boys. Levels of insulin and HOMA-IR values were significantly higher in insulin resistance group in both female and male $(\mathrm{p}<0.001)$ (TABLE 2).

\section{Amplification of bisulfite coverted DNA}

FIGURE $1 \mathrm{a}$ and $1 \mathrm{~b}$ show that the amplification of bisulfite -modified DNA (Bis - DNA) of gene promoter target region of IL6 and TLR4 was successfully performed. It was characterized by an intense single band on $2 \%$ agarose gel that is at $300 \mathrm{bp}$ for IL6 and 296 bp for TLR4 compared to DNA marker. 
Atmaja et al., Correlation of methylation of toll-like receptor 4 (TLR4) and interleukin-6 (IL6) promoter with insulin resistance in obese adolescents

TABLE 2. Mean difference between groups

\begin{tabular}{lcccc}
\hline \multirow{2}{*}{ Category } & \multicolumn{2}{c}{ Female } & \multicolumn{2}{c}{ Male } \\
\cline { 2 - 5 } & $\begin{array}{c}\text { IR } \\
(\mathrm{n}=18)\end{array}$ & $\begin{array}{c}\text { Non-IR } \\
(\mathrm{n}=7)\end{array}$ & $\begin{array}{c}\text { IR } \\
(\mathrm{n}=16)\end{array}$ & $\begin{array}{c}\text { Non-IR } \\
(\mathrm{n}=9)\end{array}$ \\
\hline Age $^{\mathrm{a}}$ & $16.78 \pm 0.7$ & $16.68 \pm 0.7$ & $16.65 \pm 0.6$ & $17.02 \pm 0.9$ \\
Z-score $^{\mathrm{a}}$ & $4.2 \pm 0.9$ & $3.16 \pm 0.6^{*}$ & $3.74 \pm 1.0$ & $3.51 \pm 1.0$ \\
$\mathrm{FBG}^{\mathrm{b}}(\mathrm{mg} / \mathrm{dL})$ & 86.5 & $77^{*}$ & 87.5 & 76 \\
& $(73-113)$ & $(68-90)$ & $(74-111)$ & $(69-101)$ \\
Insulin $^{\mathrm{b}}(\mathrm{mg} / \mathrm{dL})$ & 25.53 & $14.94^{* *}$ & 22.18 & $13.33^{* *}$ \\
& $(16.85-40.19)$ & $(9.62-18.41)$ & $(16.21-52.96)$ & $(7.08-16.99)$ \\
HOMA-IR $^{\mathrm{b}}$ & 5.15 & $2.9^{* *}$ & 4.9 & $2.5^{* *}$ \\
& $(3.8-9.2)$ & $(1.7-3.1)$ & $(3.4-10.1)$ & $(1.7-3.1)$ \\
\hline
\end{tabular}

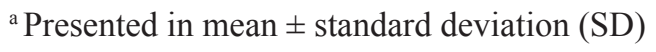

${ }^{\mathrm{b}}$ Presented in median value (minimum-maximum)

* Significance $\mathrm{p}<0.05$

${ }^{* *}$ Significance $\mathrm{p}<0.001$
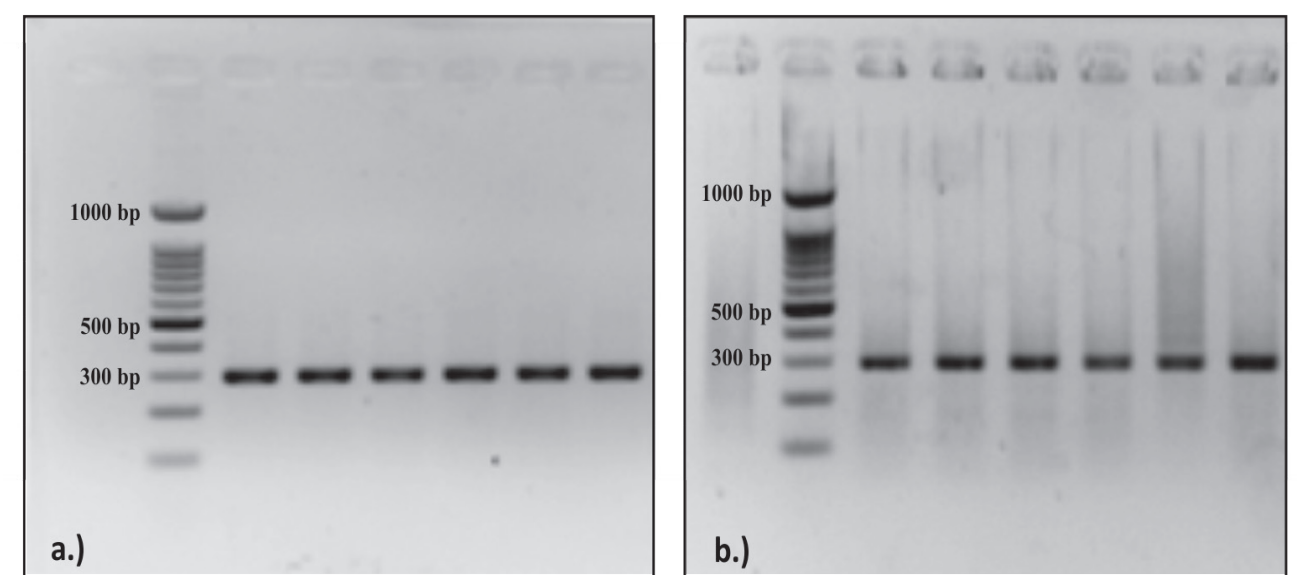

FIGURE 1. Bisulfite-modified DNA (Bis-DNA) amplicon visualization of the target region of IL6 and TLR4 gene promoter on 2\% agarose gel.

Sequencing was performed to confirm that the region amplified by the primer was a target region. The nucleotide sequences obtained from sequencing was aligned to compare with DNA sequences from NCBI using Multalin. The results show that the alignment of the amplified region is equal to the target region with nucleotide similarities $90 \%$.

\section{Direct Bisulfite Sequencing PCR TLR4}

DNA conversion was successful (FIGURE 2). It was shown from the sequence that more than $90 \% \mathrm{C}$ non-CpG nucleotide turned into a $\mathrm{T}$ nucleotide. The electrogram also did not show any background noise that could interfere the calculation of the percentage of methylation per $\mathrm{CpG}$. 


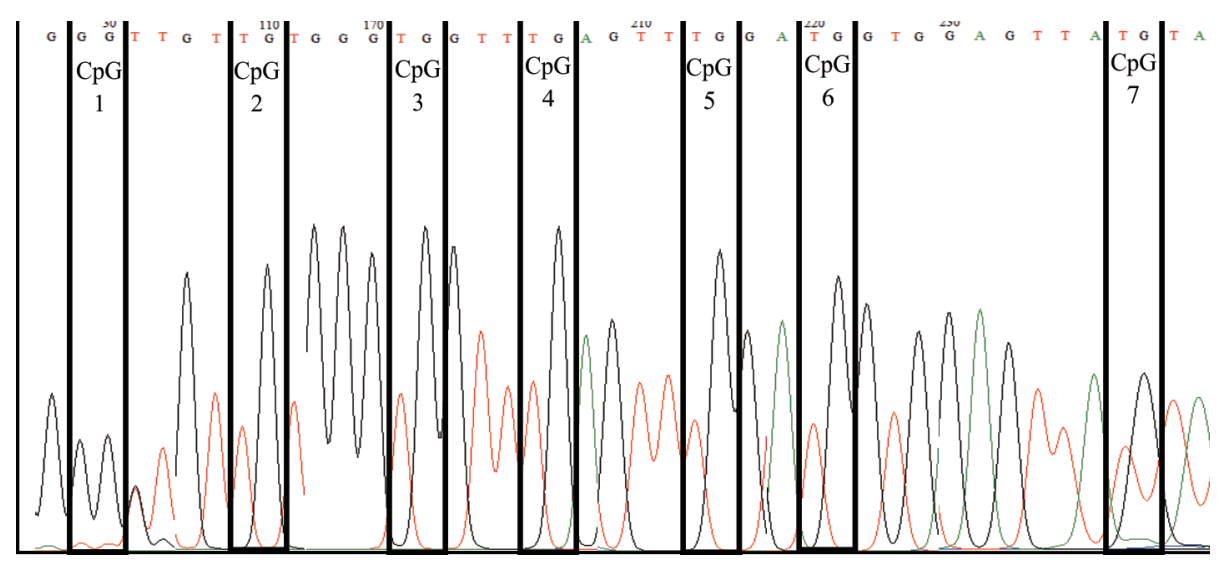

FIGURE 2. Electrogram of target region of TLR4 gene promoter. Region target arround at -94 to +202 of the TSS that include $7 \mathrm{CpG}$. There was no methylation found in all $\mathrm{CpG}$ of region target which is characterized by the entire nucleotide $\mathrm{C}$ in $\mathrm{CpG}$ turned into a nucleotide $\mathrm{T}$.

The results of TLR4 promoter region -94 to +202 sequencing showed that the entire nucleotide $\mathrm{C}$ of predicted $\mathrm{CpG}$ changed into nucleotides $\mathrm{T}$ except on CpG1. Cytosine of CpG1 (based on reference sequence) was read as guanine in chromatogram. It indicates that the entire targeted $\mathrm{CpG}$ in the target region was unmethylated. The percentage of methylation also could not be calculated because no overlapping found between nucleotides $\mathrm{C}$ and $\mathrm{T}$ in the predicted $\mathrm{CpG}$.
Targeted IL6 promoters in this study were around -290 to +10 nucleotides of TSS that includes 5 CpGs (FIGURE 3). Several overlapping peak between nucleotide $\mathrm{C}$ peak and nucleotide $\mathrm{T}$ was found in predicted $\mathrm{CpG}$ site of IL6 electrogram. Peak ratio between them was calculated using Lewin's equation to get methylation level of each $\mathrm{CpG}$.

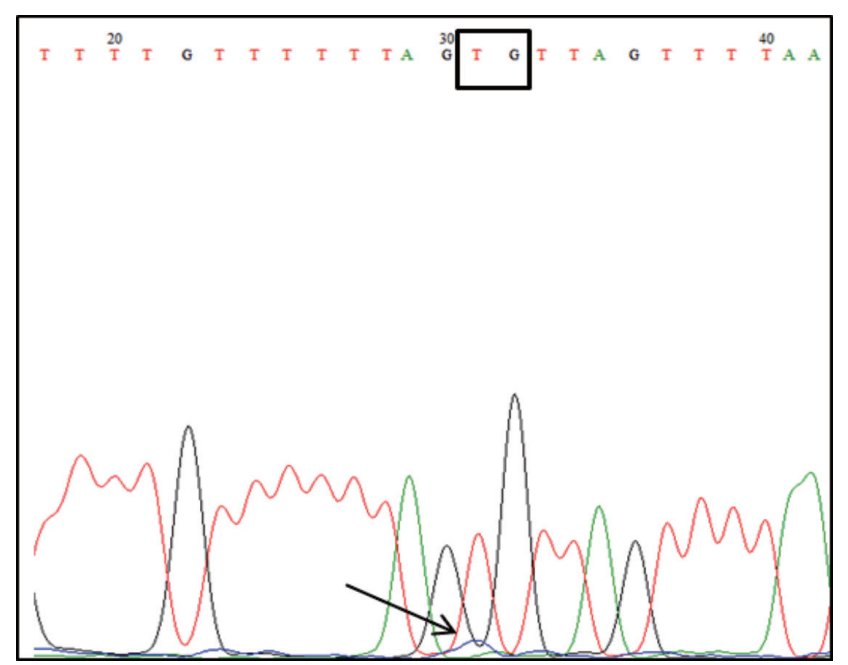

FIGURE 3. Electrogram of one of IL6 $\mathrm{CpG}$ in target region. Methylation level was obtained by calculating the ratio of peak height on $\mathrm{C}$ (blue) and $\mathrm{T}$ (red). 
Only 6 from 50 subjects showed methylation in the promoter IL6 (FIGURE 4) . The level of methylation in IL6 target region obtained in the study were very low, ranging from 0 to $12.91 \%$. The analysis was performed using different proportions of methylation level data that has been transformed into a categorical variable. Subjects who showed any methylation minimal at one $\mathrm{CpG}$ would be categorized as methylated group (TABLE $3)$.

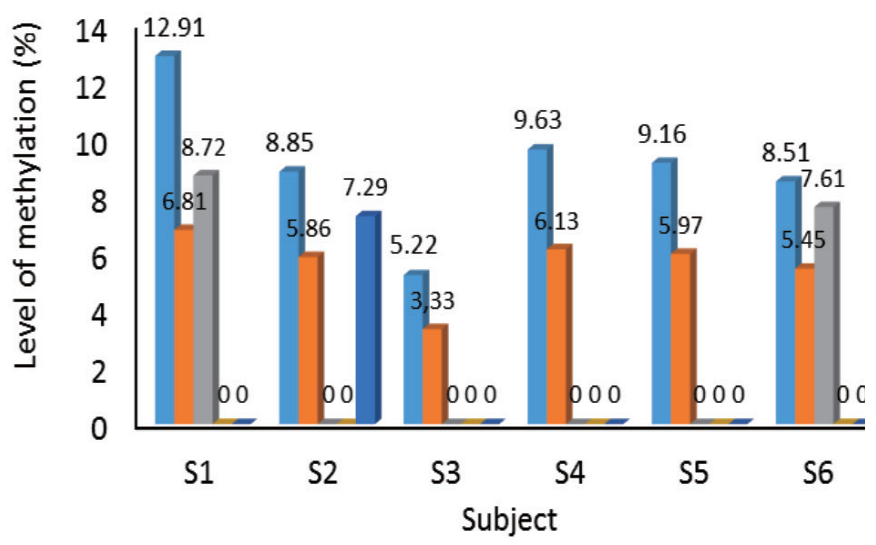

FIGURE 4. Distribution of methylation level. Only 6 out of 50 subjects showed any methylation with low level of methylation.

TABLE 3. Fisher test of methylation of IL6 between IR and non-IR group

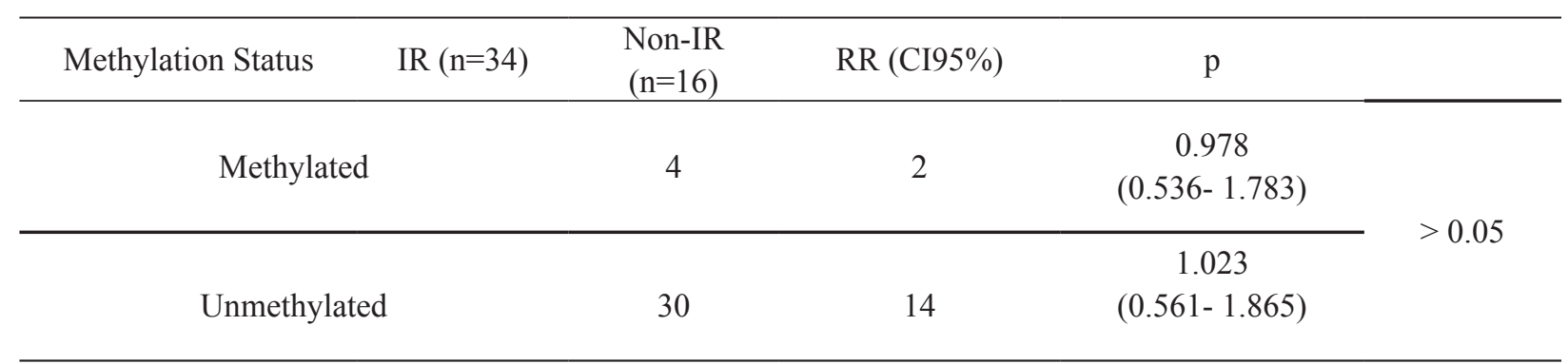

Among methylated group, $4(8 \%)$ subjects was insulin resistance while $2(4 \%)$ subjects was non-insulin resistance. Relative risk of methylated group being insulin resistance was lower $(\mathrm{RR}=0.978)$ compared with unmethylated group $(\mathrm{RR}=1.023)$. However the risk was not statistically different between groups $(p>0.05)$.

Correlation analysis by Spearman test showed that there was no statistically significant correlation found between methylation level and HOMA-IR neither with z-score, FBG level and insulin level. Significant positive correlation was shown between z-score and insulin level as well as z-score and HOMA-IR but z-score and FBG level was not correlated significantly $(\mathrm{r}=0.123)$. FBG levels with insulin levels $(\mathrm{r}=0.078)$ and HOMA-IR values $(\mathrm{r}=0.325)$ also showed a positive correlation, but only 
correlation between FBG level and HOMA IR was statistically significant. Strong positive correlation was shown between insulin level and HOMA-IR. Significant correlation was found between insulin level and HOMA-IR $(r=0.949)$ (TABLE.4).

TABLE 4. Correlation between variables

\begin{tabular}{ccccc}
\hline Variables & Z-Score & FBG & Insulin & HOMA-IR \\
\hline Methylation level & & & & \\
$r$ & -0.085 & 0.056 & -0.009 & 0.051 \\
$\mathrm{p}$ & 0.279 & 0.350 & 0.477 & 0.362 \\
Z-Score & & & & \\
$r$ & & 0.158 & $0.301^{*}$ & $0.301^{*}$ \\
$\mathrm{p}$ & 0.137 & 0.017 & 0.017 \\
FBG & & & & \\
$r$ & & 0.078 & $0.325^{*}$ \\
$\mathrm{p}$ & & & 0.295 & 0.011 \\
Insulin & & & \\
$r$ & & & & $0.949^{* *}$ \\
$\mathrm{p}$ & & & & 0.000 \\
\hline
\end{tabular}

\section{DISCUSSION}

Our data show that a total of $68 \%$ of the subjects in this study had insulin resistance (TABLE 1). These data confirm the results of the previous research that reported that more than a half of the population of children and adolescents with obesity have insulin resistance. ${ }^{20}$ The median value of insulin levels in this study was $19.28 \mu \mathrm{IU} / \mathrm{mL}$ with the range of insulin levels obtained was between 7.08 to $52.96 \mu \mathrm{IU} / \mathrm{mL}$ (TABLE 1). Although the value limit of normal insulin levels in previous studies showed varying results, insulin levels in the present study were higher than the cutoff range of hyperinsulinemia in adolescents aged 14-19 years which was 18.15 to 23.73 $\mu \mathrm{IU} / \mathrm{mL} .{ }^{21}$ A study by Rodriguez-Moran et al., ${ }^{22}$ used $16 \mu \mathrm{IU} / \mathrm{mL}$ for hyperinsulinemia cut-off category in adolescents. ${ }^{22}$ A study of cardiovascular disease in children and adolescents by the American Heart Association (AHA) established that insulin levels by 15-20 $\mu \mathrm{IU} / \mathrm{mL}$ as a borderline high of insulin normal levels. $^{23}$

A significant difference occurred between the value of HOMA-IR in the insulin resistance group and the non-insulin resistance both group. High value of HOMA-IR in this study was probably to be more influenced by insulin levels rather than FBG. This is supported by the relatively weak results of correlation test between the levels of FBG and HOMA-IR 
compared to insulin and HOMA-IR (TABLE 4). Hyperinsulinemia in adolescents has been reported to be a physiological condition which is affected by growth hormone and an increasing body mass during puberty. ${ }^{24}$ Insulin secretion will return to normal level by the end of puberty. ${ }^{25}$ However, the condition of hyperinsulinemia accompanied by obesity during adolescence may increase the risk of insulin resistance which is known as a major factor related to cardiovascular disease and type 2 diabetes. ${ }^{23}$ Low-grade chronic inflammation and imbalance levels of adipokines in obesity conditions may interfere insulin signal transduction which decreases glucose uptake by cells. The decrease of glucose uptake by cell results in increasing pancreas secretion of insulin as an effort to increase glucose uptake in order to keep blood glucose at normal level.

The degree of insulin resistance has been reported to be linear to BMI and body fat percentage. ${ }^{7}$ Insulin resistance in obesity is associated with metaflamation or inflammatory response that occurs as a result of excessive nutrients consumption. ${ }^{26}$ Free fatty acids, which is reported to be increasing in condition of obesity, are one of inducing factor for inflammatory response through TLR-4. ${ }^{13,14,27,28}$ Proinflammatory enzymes such as JNK and IKK $\beta$ which are active in downstream TLR4 signaling can lead to impaired insulin signaling through phosphorylation at IRS 1 serine residues. ${ }^{8}$ Cytokine IL- 6 , one of the proinflammatory cytokine which is secreted through TLR-4 signals, can also cause the IRS as an adapter protein loses its' function. SOCS3 which is active in IL-6 signal transduction, is able to decrease the phosphorylation of IRS 1 and even increase the ubiquitilation of IRS 1 and subsequently affect the insulin signal transduction. ${ }^{9,10}$ These cellular mechanisms not only cause chronic inflammatory conditions continue to occur, but also interfere insulin signaling, and thus the glucose uptake will be impaired. A decrease in glucose uptake will lead to the increase of insulin secretion induction.

Although all subjects were obese, mean difference test results showed that the $z$-score value affects the incidence of insulin resistance in adolescent girls but not in boys $(p<0.05)$ (TABLE 2). Level of FBG was also significant in girls group only. Insulin resistance in boy adolescent may occur by hormonal effect on the balance of adipokines. Adiponectin level was reported to decrease in obese condition. During puberty in male adolescents, adiponectin levels decrease with increasing testosterone and negatively correlate with HOMA-IR. ${ }^{29}$

Promoter methylation levels of TLR4 and IL6 in this study were detected using direct-BSP methods and were analyzed with Lewin's equation. The present study targetted \pm 300 bp promoter region of the TSS. Differences of distance between the methylated region with the transcription start site (TSS) order is known to be affecting the expression level. Methylation around TSS such as exon one, and downstream promoter significantly showed lower genes expression than methylation on the upstream promoter or intragenic region and last exons. ${ }^{30}$ A study about pattern distribution and methylation level has shown that gene with highest expression has lower methylation on region around 500bp from TSS. ${ }^{31}$ Target region in this study has transcription factor binding site as predicted by PROMO software. ${ }^{32}$ Each transcription factor was reported to have a role in the regulation of the transcription of the gene.

Based on sequencing of TLR4 promoter region around -94 to +202 , it was shown that all subjects were not methylated in all 
predicted $\mathrm{CpG}$. As far as our knowledge, no studies have reported the methylation level of TLR4 on peripheral blood cells adolescents with obesity and its correlation with insulin resistance. Studies on TLR-4 methylation has been performed in intestinal epithelial cells and gingival tissue. A study by Takahashi et al., ${ }^{33}$ using cell intestinal epithelial cell line reported that methylation at -69 to +277 serve to maintain homeostasis condition of normal flora in the digestive tract by emphasizing the expression of TLR-4. ${ }^{33}$ The different results between our study and theirs may occur because of the characteristic of methylation mechanisms itself which are specific to each cell. ${ }^{34}$ Research on TLR4 promoter methylation at $\mathrm{CpG}-646$ and -822 positions in the gingival tissues showed that almost the whole subjects in the regions were not methylated and were not associated with TLR4 mRNA transcripts. ${ }^{35}$ Because all subjects were not methylated in the region target of the TLR4 promoter, it can be concluded that there was no correlation between the degree of methylation in the TLR4 target region with insulin resistance in adolescents with obesity.

Methylation of $\mathrm{CpG}$ on the promoter region has been known to affect the effectiveness of transcription initiation complex formation. However, it was reported that methylation can also occur in untranslated regions, exons, the non-coding region, and repetitive sequence although its mechanism to influence the transcription process is not widely known. ${ }^{36,37}$ Therefore it is possible that epigenetic regulation does not occur in the target region but occurs in other regions. Remely et al., ${ }^{38}$ reported that the gene TLR4 exon 1 methylation level of intestinal cells found in individuals with obesity is lower than the control group. ${ }^{38}$ Methylation in exon 1 of a gene affects the transcriptional silencing occurence more than the promoter methylation in the upstream portion. ${ }^{30}$ However, the mechanisms of how gene's body methylation influence the transcription process effectiveness is still unknown. Methylation in gene's body is suspected to play a role in the splicing process. ${ }^{39}$

Targeted IL6 promoters in this study are inside -290 to +10 nucleotides of TSS that includes 5 CpGs (FIGURE 3). The level of methylation in IL6 target region obtained in the present study are very low, ranging from 0 to $12.91 \%$ and only 6 of the 50 subjects showed methylation in IL6 target region (FIGURE 4) Therefore, the data is transformed into categorical form with minimum requirements 1 of CpGs which shows any methylation is categorized as methylated. Fisher test results in TABLE 3 shows that the relative risk of individuals with methylation on IL6 promoter suffering insulin resistance is smaller $(\mathrm{RR}=0.978)$ compared with individuals who were methylated $(R R=1.023)$. However, there is no significant difference between the insulin resistance with no insulin resistance groups (TABLE 3).

There was no statistically significant correlation between the levels of IL6 promoter methylation with other variables such as z-score, GDP, levels of insulin and HOMAIR value. Zhang et al. ${ }^{40}$ study showed similar results which shows no correlation between IL6 promoter methylation with BMI. ${ }^{40}$ Different results were reported by Na et al., ${ }^{41}$ which significantly had more IL6 promoter hypermethylation in peripheral blood cells of women with obesity than overweight group or normal BMI group. The occuring hypermethylation is suspected as a negative feedback to suppress the IL-6 levels on the condition of obesity. ${ }^{41}$

Promoter DNA methylation may influence the transcription process by either directly inhibits the binding of transcription 
factors to the binding site or together with MBD, histone deacetylase enzyme and histone methyltransferase enzyme causing modifications of histones. The histone modification can cause chromatin structure to become more compact and therefore the transcription factor binding sites become inaccessible and the transcription process may also be disrupted. DNA methylation mechanism will lead to repression of transcription thus decreasing the expression of a gene or vice versa. ${ }^{42,43}$

Methylation around TSS such as exon-1 and downstream promoter $(250 \mathrm{bp})$ results in lower gene expression than methylation on upstream promoter, intragenic region or last exon. Nonetheless, Nile et al., ${ }^{44}$ showed that methylation on -1099 significantly represses the expression of mRNA of TLR $4 .{ }^{44}$ This may occur if the methylated $\mathrm{CpG}$ is precisely on TFBS and affects binding affinity between transcription factor and TFBS..$^{45}$

There are several possibilities of why methylation in the TLR4 promoter target region was not found and methylation in the IL6 target region was in low levels in this study. First, every subject in this study was an individual with obesity. Obesity is known as a condition due to chronic inflammation which is characterized by increased expression of TLR4 and IL6 not only on the insulin target cells, but also on the peripheral blood cells. ${ }^{11,12,28}$ Thus, low levels of methylation of IL6 in the target region or even the absence of methylation at TLR4 CpG target allegedly is indeed an up-regulation form of TLR-4 and IL- 6 on the obesity condition through DNA methylation.

Toll-like receptor 4 in circulation is mainly expressed by monocytes which are known to secrete IL- 6 mostly through the activation of TLR-4 in circulation on the obesity condition ${ }^{46}$ However, the composition of monocytes is only about $2-8 \%$ of total leukocytes in the circulation. ${ }^{47}$ The level of obtained methylation is also suspected to be very low considering that this study used a sample buffycoat and not specific mononuclear cells. Other possibilities for improvement of IL6 mRNA and TLR4 were widely reported increases in peripheral blood cells of individuals with obesity are not regulated by other DNA methylation but by other mechanisms such as mRNA stability, the effectiveness of the enhancer and suppressor, polymorphism influences or the existence of miRNA. The weakness of this study is not to measure the mRNA of TLR-4 or IL- 6 , therefore it is not known whether there is a relationship between the methylation status in the studied region with the produced mRNA transcripts. Besides, this study did not observe the levels of free fatty acids which act as an initiator of inflammation through TLR4.

The characteristics of subjects in this study had been designed to prevent bias in the obtained methylation results by determining short age limit which is $15-18$ years old and making gender stratification. Selection of stratification by gender was based on research which showed differences in methylation levels between men and women; not only in the $\mathrm{X}$ chromosome, but also in autosomes. ${ }^{48-50}$ The influence of age on methylation occurs in almost all tissues and healthy cells (noncancer) in humans and can be used to predict a person's age in forensic or can be used as a routine examination for predicting the risk of age-related diseases..$^{51-53}$

\section{ACKNOWLEDGEMENTS}

We would like to thank the children and their parents who have participated in this study.

\section{REFERENCES}

1. The American Thoracic Society. Candida Infection of the Bloodstream-Candidemia, Am J Respir Crit Care Med 2012; 185:3-4 
2. Olsen I. Attenuation of Candida albicans virulence with focus on disruption of its vacuole functions. J Oral Microbiol 2014; 6:23898. http://dx.doi.org/10.3402/jom.v6.23898

3. Elis D. Candida albicans, Mycology online, University of Adelaide. http://www.mycology.adelaide.edu.au/Fungal_Descriptions/ Yeasts/Candida/Candida_albicans.html

4. Fisher JF, Kavanagh K, Sobel JD, Kauffman CA, Newman CA. Candida urinary tract infection: pathogenesis. Clin Infect Dis 2011; 52 Suppl 6:437-51.

http://dx.doi.org/ 10.1093/cid/cir110

5. Pfaller MA, Jones RN, Messer SA, Edmond MB, Wenzel RP. National surveillance of nosocomial blood stream infection due to candida albicans: frequency of occurrence and antifungal susceptibility in the SCOPE Program. Diag Microbiol Infect Dis 1998; 31(1):327-32. http://dx.doi.org/10.1016/ S0732-8893(97)00240-X

6. Akbari F, Kjellerup BV. Elimination of bloodstream infections associated with candida albicans biofilm in intravascular catheters. Pathogens 2015; 4(3):457-69. http://dx.doi.org/10.3390/pathogens4030457

7. Cleveland AA, Harrison LH, Farley MM, Hollick R, Stein B, Chiller TM, et al. Declining incidence of candidemia and the shifting epidemiology of candida resistance in two US metropolitan areas, 2008-2013: results from population-based surveillance. PLoS ONE 2015; 10(3):e0120452. http://dx.doi. org/10.1371/journal.pone.0120452

8. Vermitsky JP, Self MJ, Chadwick SG, Trama JP, Adelson ME, Mordechai E, et al. Survey of vaginal-flora Candida species isolates from women of different age groups by use of species-specific PCR detection. J Clin Microbiol 2008; 46(4):1501-3. http://dx.doi.org/10.1128/JCM.02485-07

9. De Bernardis F, Arancia S, Sandini S, Graziani S, Norelli S. Studies of immune responses in Candida vaginitis. Pathogens 2015; 4(4):697-707 http://dx.doi.org/10.3390/pathogens4040697

10. Sobel JD. Vulvovaginal candidosis. Lancet 2007; 369(9577):1961-71.

http://dx.doi.org/10.1016/S 0140 6736(07)60917-9

11. Van Schalkwyk J, Yudin MH. Vulvovaginitis: screening for and management of trichomoniasis, vulvovaginal candidiasis, and bacterial vaginosis. J Obstet Gynaecol Can 2015; 37(3):266-76. http://dx.doi.org/10.1016/ S1701-2163(15)30316-9

12. Williams D, Lewis M. Pathogenesis and treatment of oral candidosis. J Oral Microbiol 2011; 3:5771. http://dx.doi.org/10.3402/jom. v3i0.5771

13. Zomorodian K, Haghighi NN, Rajaee N, Pakshir K, Tarazooie B, Vojdani M, et al. Assessment of Candida species colonization and denture-related stomatitis in complete denture wearers. Med Mycol 2011; 49(2):208-11. http://dx.doi.org/10.3109/13693786.2010.50 7605

14. Kelly BP. Superficial Fungal Infections. Pediatr Rev 2012; 33(4):22-37. http://dx.doi. org/10.1542/pir.33-4-e22

15. Rex JH, Walsh TJ, Sobel JD, Filler SG, Pappas PG, Dismukes WE, et al. Practice guidelines for the treatment of candidiasis. Infectious Diseases Society of America. Clin Infect Dis 2000; 30(4):662-78. http://dx.doi. org/10.1086/313749

16. Machado AG, Komiyama EY, Santos SS, Jorge AO, Brighenti FL, Kago-Ito CY. In vitro adherence of Candida albicans isolated from patients with chronic periodontitis. J Appl Oral Sci 2010; 19(4):384-7. http://dx. doi.org/10.1590/S1678-77572011005000014

17. Schmid J, Hunter PR, White GC, Nand AK, Cannon RD. Physiological traits associated with success of Candida albicans strains as commensal colonizers and pathogens. J Clin Microbiol 1995; 33(11):2920-6.

18. Calderone R, Suzuki S, Cannon R, Cho T, Boyd D, Calera J, et al. Candida albicans: adherence, signaling and virulence. Med Mycol 2000; 38(Suppl 1): 125-37. 
http://dx.doi.org/10.1080/mmy.38. s1.125.137

19. Cannon RD, Chaffin WL. Oral colonization by Candida albicans. Crit Rev Oral Biol Med 1999; 10(3):359-83. http://dx.doi.org/10.117 7/10454411990100030701

20. Tsuchimori N, Sharkey LL, Fonzi WA, French SW, Edwards JE Jr, Filler SG. Reduced virulence of HWP1-deficient mutants of Candida albicans and their interactions with host cells. Infect Immun 2000; 68(4):1997-2002. http://dx.doi.org/10.1128/IAI.68.4.19972002.2000

21. Yang YL. Virulence factors of Candida species. J Microbiol Immunol Ifect 2003; 36(4):223-8.

22. Staniszewska M, Bondaryk M, Siennicka K, Piłat J, Schaller M, Kurzatkowski W. Role of Aspartic Proteinases in Candida albicans Virulence. Part I. Substrate Specificity of Aspartic Proteinases and Candida albicans Pathogenesis. Post Mikrobiol 2012; 51(2):127-35.

23. Naglik JR, Challacombe SJ, Hube B. Candida albicans secreted aspartyl proteinases in virulence and pathogenesis. Microbiol Mol Biol Rev 2003; 67(3):400-28.

http://dx.doi.org/10.1128/MMBR.67.3.400428.2003

24. Schaller M, Schackert C, Korting HC, Januschke E, Hube B. Invasion of Candida albicans correlates with expression of secreted aspartic proteinases during experimental infections of human epidermis. J Invest Dermatol $2000 ; 114(4): 712-7$.

http://dx.doi.org/10.1046/j.15231747.2000.00935.x

25. Mardegan RC, Foglio MA, Gonçalves RB, Höfling JF. Candida albicans proteinases. Braz J Oral Sci 2006; 5(16):944-52.

26. Borst A, Fluit AC. High levels of hydrolytic enzymes secreted by Candida albicans isolates involved in respiratory infections. $\mathrm{J}$ Med Microbiol 2003; 52(Pt 11):971-4. http:// dx.doi.org/10.1099/jmm.0.05228-0

27. Monroy-Pérez E, Paniagua-Contreras G, Vaca-Paniagua F, Negrete-Abascal E, Vaca S.
SAP expression in candida albicans strains isolated from mexican patients with vaginal candidosis. Int J Clin Med 2013; 4(1):25-31. http://dx.doi.org/10.4236/ijcm.2013.41006

28. Staniszewska M, Bondaryk M, Siennicka K, Piłat J, Schaller M, Kurzatkowski W. Role of Aspartic Proteinases in Candida albicans Virulence. PART II: Expression of SAP 1-10 Aspartic Proteinase during Candida albicans Infection in vivo. Post Mikrobiol 2012; 51 (2): $137-142$

29. Ghannoum MA. Potential role of phospholipases in virulence and fungal pathogenesis. Clin Microbiol Rev 2000; 13(1):122-43. http://dx.doi.org/10.1128/CMR.13.1.122143.2000

30. Williams DW, Jordan RP, Wei XQ, Alves CT, Wise MP, Wilson MJ, et al. Interactions of Candida albicans with host epithelial surfaces. J Oral Microbiol 2013; 5:22434. http:// dx.doi.org/10.3402/jom.v5i0.22434

31. Samaranayake YH, Dassanayake RS, Cheung BP, Jayatilake JA, Yeung KW, Yau JY, et al. Differential phospholipase gene expression by Candida albicans in artificial media and cultured human oral epithelium. APMIS 2006; 114(12):857-66.

http://dx.doi.org/10.1111/j.1600-0463.2006. apm_479.x

32. Ibrahim AS, Mirbod F, Filler SG, Banno Y, Cole GT, Kitajima Y, et al. Evidence implicating phospholipase as a virulence factor of Candida albicans. Infect Immun 1995; 63(5):1993-8. http://dx.doi.org/10.1111/ j.1567-1364.2009.00570.x

33. Almeida RS, Wilson D, Hube B. Candida albicans iron acquisition within the host. FEMS Yeast Res 2009; 9(7):1000-12.

http://dx.doi.org/

$10.1111 / \mathrm{j} .1567-$ 1364.2009.00570.x

34. Rossoni RD, Barbosa JO, Vilela SF, Jorge AO, Junqueira JC. Comparison of the hemolytic activity between C. albicans and non-albicans Candida species. Braz Oral Res 2013; 27(6):484-9. http://dx.doi.org/ 10.1590/ S1806-83242013000600007 
35. Rosa EA, Rached RN, Ignacio SA, Rosa RT, da Silva WJ, Yau JY, et al. Phenotypic evaluation of the effect of anaerobiosis on some virulence attributes of Candida albicans. J Med Microbiol 2008; 57(Pt 10):1277-81. http://dx.doi.org/10.1099/jmm.0.2008/ 001107-0

36. Wibawa T, Praseno, Aman AT. Virulence Candida albicans isolated from HIV Infected and non infected individuals. SpringerPlus $2015 ; 4: 408$. http://dx.doi.org/10.1186/s40064-015-12150

37. Molero G, Díez-Orejas R, Navarro-García F, Monteoliva L, Pla J, Gil C, et al. Candida albicans: genetics, dimorphism and pathogenicity. Internatl Microbiol 1998; 1(2):95-106.

38. Mayer FL, Wilson D, Hube B. Candida albicans pathogenicity mechanisms. Virulence 2013; 4(2):119-28. http://dx.doi.org/10.4161/ viru. 22913

39. Pukkila-Worley R, Peleg AY, Tampakakis E, Mylonakis E. Candida albicans hyphal formation and virulence assessed using a Caenorhabditis elegans infection model. Eukaryot Cell 2009; 8(11):1750-8. http://dx.doi. org/10.1128/EC.00163-09

40. Saville SP, Lazzell AL, Monteagudo C, Lopez-Ribot JL. Engineered control of cell morphology in vivo reveals distinct roles for yeast and filamentous forms of Candida albicans during infection. Eukaryot Cell 2003; 2(5):1053-60.

http://dx.doi.org/10.1128/EC.2.5.10531060.2003

41. Vautier S, Drummond RA, Chen K, Murray GI, Kadosh D, Brown AJ, et al. Candida albicans colonization and dissemination from the murine gastrointestinal tract: the influence of morphology and Th17 immunity. Cell Microbiol 2015; 17(4):445-50. http://dx.doi.org/10.1111/cmi.12388

42. Kumamoto CA, Vinces MD. Contributions of hyphae and hypha-co-regulated genes to Candida albicans virulence. Cel Mi- crobiol 2005; 7(11):1546-54 http://dx.doi. org/10.1111/j.1462-5822.2005.00616.x

43. Han TL, Cannon RD, Villas-Bôas SG. The metabolic basis of Candida albicans morphogenesis and quorum sensing. Fungal Genet Biol 2011; 48(8):747-63. http://dx.xoi.org/10.1016/j.fgb.2011.04.002

44. Baillie GS, Douglas LJ. Role of dimorphism in the development of Candida albicans biofilms. J Med Microbiol 1999; 48(7):671-9. http://dx.doi.org/10.1099/00222615-48-7671

45. Jacobsen ID, Wilson D, Wächtler B, Brunke S, Naglik JR, Hube B. Candida albicans dimorphism as a therapeutic target. Expert Rev Anti Infect Ther 2012; 10(1):85-93. http://dx.doi.org/10.1586/eri.11.152

46. Xie J, Tao L, Nobile CJ, Tong Y, Guan G, Sun $\mathrm{Y}$, et al. White-opaque switching in natural MTLa/a isolates of Candida albicans: evolutionary implications for roles in host adaptation, pathogenesis, and sex. PLoS Biol 2013; 11(3):e1001525.

http://dx.doi.org/10.1371/journal. pbio. 1001525

47. Huang G. Regulation of phenotypic transitions in the fungal pathogen Candida albicans. Virulence 2012; 3(3):251-61. http:// dx.doi.org/10.4161/viru.20010

48. Sasse C, Hasenberg M, Weyler M, Gunzer M, Morschhäusera J. White-opaque switching of Candida albicans allows immune evasion in an environment-dependent fashion. Eukaryot Cell 2013; 12(1):50-8. http://dx.doi. org/10.1128/EC.00266-12

49. Anderson J, Cundiff L, Schnars B, Gao MX, Mackenzie I, Soll DR. Hypha formation in the white-opaque transition of Candida albicans. Infect. Immun 1989; 57(2):458-67.

50. Morschhäuser J. Regulation of white-opaque switching in Candida albicans. Med Microbiol Immunol 2010; 199(3):165-72. http:// dx.doi.org/10.1007/s00430-010-0147-0

51. Wibawa T. Candida albicans biofilm: formation and antifungal agents resistance. J Med Sci 2012; 44(2):1-9. 
52. Ramage G, Rajendran R, Sherry L, Williams C. Fungal biofilm resistance. Int J Microbiol 2012; 2012:528521. http://dx.doi. org/10.1155/2012/528521

53. Pierce CG, Chaturvedi AK, Lazzell AL, Powell AT, Saville SP, McHardy SF, et al. A novel small molecule inhibitor of Candida albicans biofilm formation, filamentation and virulence with low potential for the development of resistance. NPJ Biofilms Microbiomes 2015; 1pii:15012. http://dx.doi. org.10.1038/npjbiofilms

54. Wibawa T, Nurrokhman, Baly I, Daeli PR, Kartasasmita G, Wijayanti N. Cyclosporine a decreases the fluconazole minimum inhibitory concentration of Candida albicans clinical isolates but not biofilm formation and cell growth. Trop Biomed 2015; 32(1): 76-182.

55. Finkel JS, Mitchell AP. Genetic control of Candida albicans biofilm development. Nat Rev Microbiol 2011; 9(2):109-18. http://dx.doi.org/10.1038/nrmicro2475

56. Naglik JR. Candida Immunity. New J Sci 2014; 2014(ID 390241):1-27. http://dx.doi.org/10.1155/2014/390241

57. Netea MG, Sutmuller R, Hermann C,Van der Graaf CA, Van der Meer JW, van Krieken $\mathrm{JH}$, et al. Toll-like receptor 2 suppresses immunity against Candida albicans through induction of IL-10 and regulatory T cells. J Immunol 2004; 172(6):3712-8.

http://dx.doi.org/10.4049/jimmunol.172.6.3712 